Meta

Journal des traducteurs

Translators' Journal

\title{
Figurative Language in Translation: A Study of J.P. Clark's The Ozidi Saga
}

\section{Diri I. Teilanyo}

Volume 52, numéro 2, juin 2007

URI : https://id.erudit.org/iderudit/016073ar

DOI : https://doi.org/10.7202/016073ar

Aller au sommaire du numéro

Éditeur(s)

Les Presses de l'Université de Montréal

ISSN

0026-0452 (imprimé)

1492-1421 (numérique)

Découvrir la revue

Citer cet article

Teilanyo, D. I. (2007). Figurative Language in Translation: A Study of J.P. Clark's The Ozidi Saga. Meta, 52(2), 309-326. https://doi.org/10.7202/016073ar
Résumé de l'article

La traduction des expressions figurées et idiomatiques est une tâche particulièrement sensible, surtout dans les textes littéraires où la nature figurée du langage fait partie intégrante du texte en tant qu'oeuvre littéraire. Puisque la pensée moderne au sujet de la traduction favorise la fidélité au texte original, le traducteur est tenu de garder, plutôt que d'améliorer, de réduire ou de remanier autrement la texture figurée du texte original dans le texte visé (le texte d'arrivée).

Dans cet article, nous examinons la félicité de la traduction Izon-Anglais de J. P. Clark dans The Ozidi Saga. Nous faisons remarquer qu'aussi heureuse que soit la traduction en général de Clark, il y a des cas d'amélioration, d'appauvrissement et de modification perceptibles, à côté de la pleine équivalence dans la texture figurée de la traduction, lorsqu'elle est placée contre le texte Izon par un individu sensible parlant Izon-Anglais. À partir de ce qui précède, nous soutenons que n'importe quelle forme de modification rend un mauvais service littéraire au texte original, à la culture d'origine et au public visé. Nous préconisons que le traducteur du texte littéraire fasse de son mieux pour garder le niveau figuré du langage du texte original dans le texte visé (le texte d'arrivée) même si cela comprend la traduction au pied de la lettre et d'autres violations de la règle de base de la langue d'arrivée, tout en employant librement des annotations et des glossaires si nécessaire.
Ce document est protégé par la loi sur le droit d'auteur. L'utilisation des services d'Érudit (y compris la reproduction) est assujettie à sa politique d'utilisation que vous pouvez consulter en ligne.

https://apropos.erudit.org/fr/usagers/politique-dutilisation/ 


\title{
Figurative Language in Translation: A Study of J.P. Clark's The Ozidi Saga
}

\author{
DIRI I. TEILANYO \\ University of Benin, Benin City, Nigeria \\ teilanyo@uniben.edu
}

\section{RÉSUMÉ}

La traduction des expressions figurées et idiomatiques est une tâche particulièrement sensible, surtout dans les textes littéraires où la nature figurée du langage fait partie intégrante du texte en tant qu'œuvre littéraire. Puisque la pensée moderne au sujet de la traduction favorise la fidélité au texte original, le traducteur est tenu de garder, plutôt que d'améliorer, de réduire ou de remanier autrement la texture figurée du texte original dans le texte visé (le texte d'arrivée).

Dans cet article, nous examinons la félicité de la traduction Izon-Anglais de J. P. Clark dans The Ozidi Saga. Nous faisons remarquer qu'aussi heureuse que soit la traduction en général de Clark, il y a des cas d'amélioration, d'appauvrissement et de modification perceptibles, à côté de la pleine équivalence dans la texture figurée de la traduction, lorsqu'elle est placée contre le texte Izon par un individu sensible parlant Izon-Anglais. À partir de ce qui précède, nous soutenons que n'importe quelle forme de modification rend un mauvais service littéraire au texte original, à la culture d'origine et au public visé. Nous préconisons que le traducteur du texte littéraire fasse de son mieux pour garder le niveau figuré du langage du texte original dans le texte visé (le texte d'arrivée) même si cela comprend la traduction au pied de la lettre et d'autres violations de la règle de base de la langue d'arrivée, tout en employant librement des annotations et des glossaires si nécessaire.

\section{ABSTRACT}

The interlingual translation of figurative expressions and idioms is a particularly sensitive task, especially in literary texts where the figurativeness of the language is an inalienable part of the text as a literary piece. Since modern thinking on translation favours fidelity to the source text, the translator is required to maintain - rather than improve, reduce or otherwise alter - the figurative texture of the source text in the target text.

In this paper, we investigate the felicity of J.P. Clark's Izon-English translation in his The Ozidi Saga. We point out that felicitous as Clark's translation is in general, there are noticeable cases of improvement, impoverishment and alteration, alongside full equivalence, in the figurative texture of the translation when viewed against the Izon text by a sensitive Izon- English bilingual. From this we argue that any form of alteration is a literary disservice to the source text, the source culture and the target audience. We propose that the literary translator should do his utmost to retain the figurative level of the sourcetext language in the target text, even if this involves literalism and some other violation of the basic code of the target language while annotations and glossaries may be freely employed.

\section{MOTS-CLÉS/KEYWORDS}

figurative language, enfiguration, defiguration, alter-figuration, literal refiguration 


\section{Introduction}

Figurative language is one of the features that gives literature its distinctiveness in the form of the "suggestion or indirection, and imagination or invention" that characterise its method of expression (Egudu 1979: 3). It also constitutes a great part of the "intellectual pleasure" that literature affords us (Egudu 1979: 70). We are not suggesting here, however, that figurative language is peculiar to literature. In fact, figurative use is common in everyday speech, employed to indicate the speaker's deep perception of or emotive identification with the idea being expressed. It is also freely adopted for general oratorical effect. Nevertheless, figurative language is often more deliberately sought in literature such that a non-literary work employing figurative language profusely may be considered to be crossing into the realms of literature.

Figurative language involves "a deviation from what speakers of a language apprehend as the ordinary, or standard significance or sequence of words, in order to achieve some special meaning or effect" (Abrams 1988: 63). Figurative language is often divided into two classes: (a) "figures of thought" or tropes, and (b) "figures of speech" or rhetorical figures or schemes (Abrams 1988: 63; Leech 1969: 74). Tropes are those figures which involve a use of words in a way that effects a conspicuous change in their standard or literal meaning (Abrams1988: 63; Hawkes 1979: 2) or "foregrounded irregularities of content" (Leech 1979: 74) while schemes involve a departure from standard usage arising not essentially from a shift in meaning but from the unusual arrangement of the words or "foregrounded repetitions of expression" (Leech 1969: 74). The dividing line is not clear and considerable disagreement exists among scholars in the field (Abrams 1969: 63; Leech 1969: 74-75), such that some critics and theorists like Lawrence Perrine use the expression "figure of speech" to include both tropes and schemes while Hawkes uses "figure of speech" for tropes like metaphor (Hawkes 1969: 2). Indeed, schemes qualify as aspects of figurative language when the latter term is used in the broad sense of "any way of saying something other than the ordinary way" (Perrine 1963: 116) but they may not qualify when we take the narrow definition of a figure of speech as "a way of saying one thing and meaning another" (Perrine 1963: 116) or as “language which doesn't mean what it says" (Hawkes 1979: 1).

Whichever the classification, the rhetorical figures or schemes include apostrophe, rhetorical question, chiasmus, zeugma, rhyme, hyperbation, etc. We shall leave these for treatment elsewhere (as they feature in Clark's The Ozidi Saga). For now we shall look at Clark's treatment of tropes, together with some figures of sound (which are schemes, strictly speaking) in his translation, The Ozidi Saga (henceforth Saga). The tropes include simile, metaphor, metonymy, synecdoche, personification, litotes and euphemism, hyperbole, irony, paradox and pun. We note that metaphor is the chief of tropes, "the fundamental "figure of speech," since it encapsulates the basic idea of transfer of meaning, most other tropes being shades or versions of this transfer in "metaphor's prototype" (Hawkes 1979: 2).

Figurative language is of significant interest in the translation of literary works since the figurativeness of the language is crucial to the literariness of (the language of) the work. Hence a literary translation would be expected to retain in the target text (TT) the level of literariness in the source language (SL) of the source text (ST). Accordingly, we expect the literary translator to be discreet in handling this area such 
that he neither diminishes nor unduly improves the literary texture of the ST. Hence Michael Riffaterre says that the literary translator must "semiotize forms and sounds of the original" to maintain "the indirection of meaning that is the pivot on which literariness stands" such that his translation "must render both meaning and significance" which the reader will discover through this "double decoding" (1992: 204). Similarly, K. Lotfipour-Saedi has argued that the "the degree of indirection" and the "aesthetic" or "special" effect "which a literature-text is argued to have on the reader" should be maintained in a translation (1992: 95). How well Clark is able to do this is what we investigate in this paper. What we hope to demonstrate is that Clark's treatment of figurative language in the Saga is inconsistent and has often resulted in significant enrichment and improvement or some other form of modification of the figurative texture of the language in the ST.

In this task, the rest of this paper is divided into sections which discuss the different ways in which Clark treats figurative expressions, namely conferment of figurative texture, removal of figurative texture, substitution of figures and the literal re-expression of figures. We then discuss their effects in terms of their strength(s) and weakness(es) regarding their reflection of the figurative value of the original text.

Our findings advance the argument that Clark's resort to free translation and free employment of his creative genius has often compromised current demands in (literary) translation which favour unalloyed loyalty to the original text and insist that "the translator's goal must be to provide his reader with the same pleasure as reading the work in the original language offers to the man educated in this way, whom we usually call, in the better sense of the word, the amateur or the connoisseur" (Schleiermacher 1992: 44).

\section{Conferment of figurative texture}

The most prominent feature of Clark's handling of figurative language is the replacement of literal expressions in the Izon ST with figurative expressions in the English TT. In each of the following instances - the page references in the Saga are in round brackets - we give the expressions in both the ST and the TT as well as what would have been a more loyal translation (in square brackets):

1. Ogueren so be orisi fa sinde.

Ogueren had no stomach again for battle.(115) - Metaphor

[Ogueren had become completely lethargic/weary of the fight]

2. Ogueren orisideyee

Ogueren began to flag in spirit. (116) - Metaphor

[Ogueren become weary/languid]

3. Buo weneya, wariyee

Buo weneya ware ke lame

When legs take a step, it's home. $(141)^{1}-$ Metaphor

[Leg walks and gets home]

4. E, tebebirise ba fa...

Yes, her senses fled her...(133) - Personification/Animistic Metaphor

[Her head was no longer there ].

5. Owounbo pake tebe be due, due, due due.

Smoke clouds belched out of her head in regular curls.(298) - Animistic Metaphor. [...came ...] 
6. ... amene mu Odogu yo la de. ...they had arrived Odogu's den. (222) - Hyperbole

[...they reached Odogu's place]

7. "E, yeiama wo nana de, o gbobo se korein"

"Yes, the husbands we have, with shines like buttress roots (233) - Simile

[Yes, the husbands we have, with shines hard/prominent]

8. Beni peree ke omo suo emi?

Right now, is it a throne he is sitting on (149) - Metonymy

[Now he has entered into kingship (?) / It is kinship he is now in (?)]

9. Oreame, pei kpo peia

Oreame merely turned a deaf ear (185) - Metonymy

[Oreame listen itself did not listen . / Oreame did not even listen. ]

10. (a) Ebeyain fomo de.

Fomo go, go, go, go.

Ebeyai fainted outright

He quite passed out, his limbs twitching and stiffing (168) - Euphemism

(b) ....ala-a fomo zole zole...

Ala-a bo ba fomo de...

$\ldots$ and next when he fainted...

And when he passed out a second time... (242) - Euphemism

11. (a) "... ye ene engbe kon woso o pou..."

"...I only have to weigh him down with my pendulous balls" (214) [scrotum]

(b) "Engbe kpo o pou koromo mere ke ton"

"Of course, I shall push him over with my balls." (215) [scrotum]

(c) ...Engbe-sibe-owei pake mene engbe mo teku. ...the Scrotum-King tended his bag. (228; also 218, 225, 229)

(d) Ane opu engbe be kon desi ya zua seri ya...

And previously he could hop with that huge budden (228)

12. "E Ozidi, o mo timi mu pa ya sei ka emi yo"

Hey, Ozidi, if we go on like this, it will not turn out well. (329) - Litotes [“... it will be bad"]

In each of the cases above, a figurative expression has been substituted for a literal (non-figurative) expression. Excepts 1 to 5 involve metaphor where the English literal meanings of the Izon lexical items orisi, ware, ba fa and pake are supplied by us as given to us by Izon-English dictionaries (Agbegha 1996: 50, 64, 30 53; Williamson and Timitimi, 1983: 195, 57,142). In 3 the metaphor is apparent as we find, in the second line, the literal "walks" for wene rather than the metaphorical "take a step." Excerpt 6 involves hyperbole in that the literal yo ("place") has been supplanted by "den" which exaggerates or intensifies the dread in Odogu's residence, giving the TT reader a sense of awe that would hardly have been experienced in the ST. In 7 Clark has resorted to simile - "like buttress roots" - in order to capture the force of the ideophonic word korein. $^{2}$ While both evoke some image in the mind's eye, "buttress root" brings a more specific, vivid and life-like visual image.

In 8 and 9 there is the employment of metonymy. "Throne" is a metonymic representation of kingship. Clark must have had some problem with the verb suo literally "enter" (Agbegha 1996: 58); hence pere suo would non-figuratively mean to enter into kingship. Similarly, turning a deaf ear in 9 is a metonymic equivalent for pei ("listen" - Agbegha 1996: 53). Examples 10a and 10b are identical in having the literal "fainted" for fomo in the first occurrences and the euphemistic "passed out" in the second ... In 11 Clark has used "pendulous balls, "balls," "bag" and "budden" for engbe. But just 
as he has done in the descriptive, stock proper name Engbe-sibe-owei ("ScrotumKing") in 11c above, there are some places where he uses the literal "scrotum."

13. ... engbe bebe, ba se engbe engbe....

... because that scrotum of his, that scrotum of scrotums. $(217$; also 228, 229)

Extract 12 is a type of litotes in which "turn out well" is negated by "not" in order to express the negative sei ("bad") in the ST.

There are occasions where the figuration is not a substitute for an ST literal expression but is rather additional to the literal expression (which is itself translated into the TT). It often takes the form of simile. Thus in

14. Ozidi pake meyan zigbo tie emi And Ozidi stood anchored like a tree. (357)

15. Dumoubo bolou kekere ekise tebe se para para, moke timi me

Her hair previously, was in bits and prices, her head half and half like a doubleheaded hatchet. (358)

The similes have been added by Clark, probably to reinforce the sense, but they do not replace any expression in the ST as there are no lexical items equivalent to "like a tree" or "like a double-headed hatchet" in the Izon. Similarly in

16. Nene o mene mien weremi eyi be, meyan, Oreame na bise, kekere o pele na ba wan deia bese na kon a gboloa.

It also happened that his secret that Oreame had not detected this Protean power of his that enabled him to change when cut up. (194)

there is addition of "Protean power" which is a classical allusion to the Greek sea-god, Proteus, reputed to be capable of taking different shapes.

This endowment of figurative quality may also be extended to include phonological parallelism in the form of figures of sound introduced into the TT by Clark where there was none in the ST:

17. Angobo omou bo paapake tein korode. Sweat flowed freely from his body. (119)

18. Badoba pake mayan kene zelee gbidin koro pake gbogbolabatimi Badoba tumbled and toppled over like a log all outstretched. (158)

19. ... Ofe kiri kpo duo tolu bo bo mene, meyan kpo duo tolu bo bo mene, meyan kpo duo tolu bo bo mene...

Ofe chased round the field, now bobbing up here, now popping up there. (175)

20. "E mene done eyi keme la fea bra mien ka ye o"

"You can be quite mingy and skimpy with dishes." (347)

In 17 and 18 Clark has introduced some alternative effect, with 17 echoing Samuel Tayor Coleridge's famous line "The forrow followed free" ("The Rime of the Ancient Mariner," line 104). In 19 what we have in the ST is a triple verbal repetition of a clause meyan kpo duo tolu be mene which is also mimicked (twice) in the TT but in addition there is the phonological bonding between "bobbing" and "popping" introduced. ("Here and "there" in the TT are parallel to meyan repeated in the ST.) In 20 "mingy and skimpy" is purely an ornamented equivalent of the idea of not putting enough food in a pot. That these instances of alliteration, consonance, assonance, "syllabic congruence" and other phonological parallels have given additional reinforcement to the message expressed is obvious. 
There is an exception in

21. ... be egbele bo mo amene akpabo mo se karai.

His belts and bags all intact

where the alliteration between "belts" and "bags" is not deliberate since those are the normal English words for egbele and akpa (which also have a bond in the repetition of the velar-bilabial/gb/and/kp/).

We suggest the term ENFIGURATION for the practice illustrated above, that is, the practice of substituting (or introducing) a figurative expression in the TT (and YL) for a concept or idea that was expressed literally in the ST (and SL).4

\section{Removal of figurative texture}

This involves the substitution of a literal expression in the TT for an expression that is figurative in the ST. The following involve euphemisms in the Izon, made literal in English:

22. "Mu de dein bai were de seri ya wo lee ke tei ye."

Go, and tomorrow we'll make love in secret (235) ["play"]

23. (a) "Ane be emi e tiri pa de ye."

"But at this moment I'm menstruating" ["I'm outside"]

(b) Oreame gbade, "E tiri pa emi ye."

But Oreame demurred. "I'm menstruating” ["I'm staying outside"] 250)

24. Kene e bo ere dein de."

"Indeed I was already past child-bearing." (256)

[Literally "Indeed I had become a woman nighted]"

25. (a) Tie sinbo, aro karai sin, sibeyebo aro kene sei fa!

With all in position, the craft was fitted, complete with all manner of fearsome guns. [handled/carried things]. (376)

(b) Amene kekene Ozidi are yem tain be kene sibeyebo seri fie de.

And from the moment they spotted Ozidi, the gun began to roar. (377)

(c) Engrandon wan kene amere ma sibeye mo...

...out surged the Small Pox King himself, his two guns slung over his shoulder... (384)

(d) E-e sibeyeama!

They, what guns! (384).

26. "Miene e bein taimo ne bria o"

"Please get up so I can heat you water to bathe." (378) [set water for you]

In 22, although "make love" is itself an indirect reference to having sexual intercourse, its frequency of use has greatly vitiated its euphemistic quality, an effect that is intact in the word tei ("play" - Agbegha 1996: 59 ) used in the Izon ST. In 23 the Izon consider menstruation an idea not worth mentioning literally in the open. In fact, the woman's state (of "uncleanness" or "impurity" as it was considered in ancient Israel as noted in the Bible - Leviticus 12: 2-5; 15: 19-33) is considered with great distaste, as Clark notes: "In this monthly state, the Ijo woman stays outdoors as an unclean creature" (Saga, 206, Note 19). Hence it is this practice of staying outdoors that is used euphemistically in referring to her physiological state. In 24 dein (night) is used as an intransitive verb (Agbegha 1996: 19) and ere is "woman"; hence the idea of being past childbearing is expressed metaphorically as night having come on her fertility, her feminine productivity. Excerpt 25 brings the euphemism sibeye used 
widely among the Izon in place of alagba (Agbegha 1996: 6) in reference to "gun." It serves the purpose of hiding the fact from children and strangers who may not be well grounded in Izon idiom even if they can communicate in plain Izon. In 26 the euphemism derives from the fact that for water to be heated, it must be set on fire from firewood; hence setting water is synonymous with heating the water.

We propose, the term DEFIGURATION for this process, the practice of substituting a literal expression in the TT for a figurative expression in the ST.

There are few cases that may sound "defigurative" but would be exceptions. For example, in

27. E ba adou-a.a

"I won't woo her now!"

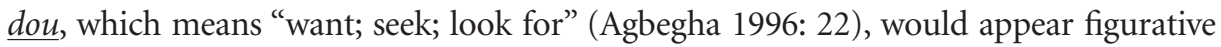
(euphemistic) but there appears not to be any other words or way of expressing the ideas of wooing or courting a woman. Hence "woo" may not be a clear case of figuration.

\section{Alteration of figuration texture}

In this case the expressions in both the ST and TT are figurative but the figurativeness has been modified. We advance the label ALTER-FIGURATION ${ }^{5}$ for this, that is, the practice of substituting a figurative expression of a particular type or in particular terms in the TT for another figurative expression of a different type or term in the ST.

There are two sub-types. In one sub-type, ALTER-FIGURATION TYPE I, a trope is replaced by another expression that belongs to a different figure or trope. The most conspicuous example of this we find is Clark's handling of the female genital "vagina" - just as he had done with engbe or "scrotum" in (11) above - and the idea of sexual intercourse:

28. (a) Tu kpo are bonogha.

I've found no woman to sleep with. (41) [...no vagina to have-sex-with]

(b) Owo a bono a ne.

He must have slept with her already. (280)

(c) Ba ton are ba la bono an! ${ }^{6}$

Since she couldn't have him in bed with her. (283)

(d) Kon ebibra a bono a keme.

The one who didn't bed her sufficiently. (285)

(e) Pa kumo tu bono an!

All his life he had not slept with a woman (287).

(f) Be gbai erein ke o bo tu bono tolumo de.

It was on this night he was now to take a woman for the first time. (287).

(g) "Ba e bono ma bra kere ba base bono ogola ke suo de? ${ }^{7}$

A ma, e mene orukumo se na tu bono bra an ye o"

To have you, is it that we shall now go into court proceedings for??

Woman, all along, I haven't known how to make love. (288)

(h) "... keme ke bo e mene konbono dou mene ye...

... who ... has carried me off to sleep with ... (289)

(i) "... e welewele ke pre bono mene ye."

"I spread out for you, and you can come in ." (289) 
(j) ... a ekpiri timi ne bo dein la ne bono-nese... ... but when night came and he sought her again to mount her ...

(k) "O emene Odugu ta kon mu wan were bono tei mene yan o!" "Is it I Odogu whose wife has been borne off to become a thing for bed play!." (293)

In all the cases above, Clark has avoided mentioning the lexical item "vagina" or "vulva" for tuu (Agbegha 1996: 62). In Izon the verb bono serves for both "to sleep" (as rest) and have "to have sexual intercourse with" ${ }^{8}$. When it means "to sleep," bono is intransitive, while it is transitive when it means "to have-sex with." Hence tu bono means "to-have-sexual-intercourse-with vagina" where tu (vagina") is the direct object of bono (have-sex-with). This involves a synecdochic representation of the woman with the "vagina" (tu $)$. In the extracts, Clark has substituted several euphemisms "woman to sleep with," "have," "come in," "to mount" and "bed play' - for the synecdoche tu bono (literally "to sex vagina," with "sex" conditioned as a verb, or "to sleep vagina"). Clark seems to be taking advantage of the homonymy in bono to dodge the direct reference to sex. It is quite obvious that Clark is uncomfortable with mentioning "vagina" (or he wants to save his TT reader from wincing at the mention of it) since even where there is no mention of $\underline{b o n o}$, he still prefers a euphemism for $\underline{t u}$ :

29. Be ke tu emi bra se, nemi an. What the female organ looked like, he had no idea. (287)

Similarly, even, where he is able to use the word "sex" for bono, he still leaves out "vagina" which is mentioned $(\underline{t u})$ in the ST:

30. "Tu bono la de a bo e."

"It could not be more than sex." (287)

Clark has clearly used "sex" to envelop both $\underline{t u}$ and $\underline{\text { bono }}$

Besides the above, there is an eloquent case of ALTER-FIGURATION 1 in

31. ... kene eyoro tobou wan duo pa bo a, benibelai

... and a girl came walking in, like a goddess out of the stream. (371)

where benibelai is "water-goddess" (288). But while in the ST the expression is an equative metaphor ("the girl came walking in, a water-goddess"), Clark's translation has expressed it as a simile with "like."

The second sub-type of modification of figurative texture is ALTER-FIGURATION TYPE II. This is involves a situation where the expressions in both ST and TT belong to the same figure of speech but the specific terms have been altered. For example, the figure may remain metaphor with the same "ground" in both ST and TT but the "vehicle" is altered (Leech 1969: 153-155). Where it is a figure of sound, it is only the specific phoneme (vowel, consonant) that changes in the two texts.

32 ... kilema tan Ofe peremene, Kemepara peremene

It poured praises upon ofe, poured on Kemepara. (65)

[Gathered praise names gave Ofe, gave Kemepara]

33. You mene me tebe ba fa.

He cried off his head. (251) [He cried until he had no head any longer.]

34. Odogu ko owo gbana timi-i-i-i kene abubu kon ayo a kiye bra...

So Odogu dealt at him incessantly, the blows falling as on a bag of sand.. (280)

[Odogu carried and put (blows) on him] 
35. Be ye odan, ye odan pesee purupuru koroani.

Let me but stamp here, and I mash it to bits and pieces (65)

36. A mese bra kere koro mulei ekpiri mulei time ne be gba be...

While they fell to dallying, rolling and petting ... (3510)

37. "A bie, e kpare kpare koro o, a beli!"

You fellow, all knob and nail that you are!" (183; also 184)

38. "Solo solo ke mo"

"Such harum-scarum!

39. Ba beni bou kpo ba solo-solo de

Now to drink water, there's hoity-toity. (214)

40. Solo pa solo.

The hustle and bustle of it. (237)

41. A kpo kene mu mene bo worose worose

Kene tain la kere worosi, worosi, worosi.

And so she went to him, limpid and languorous.

Following with sweetness and softness she was. $(287-780)$

In 32 the double verbal pattern of "Gathered ... give" in our literal translation is a feature in Izon grammar where several verbs (not auxiliaries) combine in a single verb phrase (Williamson $47 \mathrm{ff}$ ). Both tan ("gather"- Agbegha 1996: 58) and Clark's "poured" are metaphorical as they would normally be collocated with an object with the feature (+ concrete) rather than kilema ("praises") which is (- concrete) but certainly to "gather ... give" and to "pour" are different "vehicles" for the same "tenor:" (Leech 1969: 153-156). We may compare this with

42. Ama ne lulou fie mene ne meyan kpo duo pa mane wan dou pa mene.

So loud was the town with ululation, it poured from this direction, it poured from that ahead. (25)

where "poured" is used for pa which is "came out" (Agbegha 1996: 53) in reference to lulou ("ululation"). In 33 the use of tebe ("head" is hyperbolically metaphorical in itself but the change in terms is in $\underline{b a f a}$ ("no longer there/was") and "cried off." In 34 the concretising metaphor of carrying sword blows and heaping them on one's head is replaced by the metaphor of "dealing at" that person.

From 35 onward we have phonological schemes. The Izon expressions are essentially ideophonic but these are replaced by instances of alliteration, consonance and other morpho-phonological reduplicatives (Quirk et al. 1985: 1579-1580). Hence in 35 pesee gesee purupuru is translated into "bits and pieces" whose initial bilabial plosives and final alveolar sibilants produce a phonological effect that corresponds to that of the Izon expression. Similarly, the repetitive mulei mulei in 36 is replaced by "dallying, rolling, and petting" which has the consonance. So also do we find the velar-bilabial /kp/ in kpare kpare replaced with the alternatives "knob and nail" in 37. Examples 38 to 40 are clear examples of substituting English reduplicatives - "harumscarum," hoity-toity" and "hustle and bustle" - for the Izon Solo ... solo. In 41 Clark has ingeniously mimicked the differences in the vowels of worose and worosi by using alliterative/consonantal pairs "limpid and languorous" and "sweetness and softness."

\section{Identity in figurative texture}

This is the last pattern of treatment given figurative expressions by Clark in his Saga. In this pattern there is not even the least modification (at least no conspicuous 
alteration) of the figurativeness of the expression in the process of translation in that the figure of speech remains the same in type and in terms ("ground," "tenor" and "vehicle"). We may tag this LITERAL REFIGURATION - that is, the act of faithfully retaining or reproducing in the TT the very form and quality of a figurative expression in the ST. The following are instances:

43. EGBERI AREYA

APEIMENEKE TON?

IF YOU SEE A STORY

WILL YOU LISTEN? $(144,207,285)$

44. Bou ba teri fa de

And again all the forest cowered (161)

45. ... amene egberi kon bolou miemo de

... she took the matter a stage further. (293)

46. "Bengbai a owo are taba mo be!"

"Indeed, there's a broth for us both to lick today!" (296)

47. Odogu kon owo gbana timi-i- $i$-i, kene abubu kon eyo a kiye bra...

So Odugu dealt at him incessantly, the blows falling as on a bag of sand ... (280).

48. Kime koro ye bra.

... like a thing fallen in a storm. (306)

49. Kekene aveven o pele mene yan bra

It was now like cutting up a dragonfly. (368)

50. "... wo bain an timi yan ye tua kon timi me"

"... if we hadn't taken to our heels you'd have taken us along." (310)

51. ... Ozidi owei keme ye dono de.

... the male thing began to tug at Ozidi. (287).

52. ... Eyi bo o dono de.

... then the thing began to tug at him. (288)

Excerpt 43 gives us a literal translation or "relexification" of the synaesthetically metaphorical use of are ("see") to collocate with egberi ("story") which has the feature (-concrete) while "see" would normally take an object that is (+ concrete). ${ }^{11}$ The normal verb would have been $\underline{n a}$ ("hear" - Agbegha 1996: 44.). Similarly, in 44 teri (to "cover; close; shut" - Agbegha 1996: 59 - as with a hat) which is in the passive voice as a concretising metaphor is translocated "verbatim," so to say, into the TT with the word "cowered." In 45 the lexical item "took" is a literal equivalent of kon (Agbegha 1996: 390), both being figurative in taking as object the abstract egberi (literally "story" but contextually "matter"). Similarly literalism obtains in 46 . Extracts 47 to 48 are instances where the simile in the English is a direct take-over from the Izon utterance including the comparative marker bra ("like," "as" or "in the way of" - Agbegha, 1996: 18). Extracts 50 to 52 are identical. In 50 tua kon and "taken ... along" are used euphemistically for "kill" in that in the story, Ozidi's attendants are relating their escape from their master Ozidi's sword that has just mistakenly slain his grandmother-mentor Oreame. Hence a few utterances earlier we had read:

53. "Be emi ye o la were kpo ye okpo tua de ya?"

"As it is, had you got to us you could also have murdered us." (310)

In both 51 and 52 we find the Izon euphemisms for the male genital organ owei keme ye (literally "male person thing") and eyi ("the thing") rather than ton ("penis" - see Note 5 above). This contrasts with the female genital mentioned in its raw form in the Izon (ALTER-FIGURATION 1 above). 
There are a few expressions which appear like literal refiguration but this is not particularly so since what appears figurative in the ST is just the normal way the Izon speak. We find this in the expression of hunger:

54. Eyibo fiedese, omene mounbose ba kene kpo kerea....

Once those instruments spoke, hunger could no longer hold him ...

55. "O, so moun ke e kere mene?"

"So, it is battle hunger gripping you?" (321)

Here the collocation of "hunger" with "hold" and "gripping" is deviant, giving the semblance of an animistic metaphor; but this is just the normal unmarked (rather than figurative) way of expressing it in Izon (as indeed in several other Nigerian languages).

\section{Discussion}

We have identified four or five different ways in which Clark has handled figurative language in his Saga, namely endowment of figurative texture (enfiguration), removal of figurative texture (defiguration), modification of figurative texture (alter-figuration I and II) and sameness of figurative texture (literal refiguration). These patterns result in different relationships between the ST and the TT in terms of the level (range) of fidelity or loyalty which the latter bears towards the former. Clark seems to have used "transposing presuppositions" which involve "either making the implicit explicit or a lateral displacement whereby the semiotic detour, a figurative turn of phase for instance, will be replaced by a metonym of the representative that was blocking the way" (Riffaterre 1992: 207).

As Hawkes has put it, metaphor (and figurative language in general) when "deliberately invoked, intensifies language's characteristic activity, and involves, quite literally, the creation of 'new' reality" (1979: 29). Since figurative language brings "new reality," additional literary value, ornamentation or embellishment to any utterance, enfiguration clearly results in enrichment of the ST. It results in a figuratively wealthier TT in comparison with the ST.

This tendency to (artificially) enrich the ST in the translation is most readily associated with poet-translators and is the principal argument translatologists hold against creative literary artists in that they are wont to display their creative, poetic genius, including the introduction of figurative texture where there was none. Hence Hugo Friedrich protests this "creative ambition" on the part of "distinguished writers ... writer translators" because "instead of maintaining the style of the original, they elevate it" (1992: 16). Such unwarranted elevation of the stylistic quality of the ST is frowned upon by translatologists who hold fidelity as the watchword. Octavo Paz holds that "in practice, poets are rarely good translators" (1992: 158) on account of their failure to tame their creative instinct, in submission to the dictates of the ST. "They almost invariably use the (original text) as a point of departure toward their own” (Paz 1992: 158). George Steiner states the issue quite eloquently:

Often, the translator feeds on the original for his own increase. Endowed with linguistic and prosodic talents but unable to produce an independent, free life-form, the translator ... will heighten, overcrowd, or excessively dramatise the text which he is translating to make it almost his own trophy.

The most interesting examples of 'transfiguration' from both a technical and cultural point of view, however, are those in which a 'betrayal upward' takes place as it were, 
unwittingly. The translator produces a piece of work which surpasses the original in stylistic quality or in emotional scope... yet however brilliant the yield, the process is one of 'overcompensation'; and the cardinal balance is broken 'A translator is to be like his author, wrote Dr. Johnson in reference to Dryden, 'it is not his business to excel him.' Where he does so, the original is subtly injured. And the reader is robbed of a just view. (Steiner 1975: 402)

In other words, enfiguration favours essentially the egoistic whims of the writertranslator but disfavours the ST and, particularly, the reader of the TT. It follows that Clark ought to have invested his linguistic genius, including enfiguration, in his own creative adaptation of the story in his play Ozidi, while leaving literal (non-figurative) expressions in the English ST as far as the Saga is concerned.

Ime Ikiddeh has noted "the verbal poverty in narrative resourcefulness and grasp and the absence of verbal lustre that marks a good deal of Okabou's [Izon] text" of the Saga such that "the verbal performance as recorded in the translation often stays at the level of the common folktale" (1982: 53, 55). Hence "any reservation on the epic status of The Ozidi Saga is likely to be in the area of language" (Ikiddeh 1982: 55). And since "all power comes from the original, then we must also accept the notion that the stylistic features of the translation should conform to those of the original, even when the original text is written in an ordinary or lower class style" (Friedrich 1992: 16). Consequently "to smooth it over or to embellish it," says August Wihelm Schlegel, "would be to destroy it" (Schulte and Biguenet 1992: 4). But Clark's enfiguration has attempted to elevate Okabou's Izon ST, probably to give it the sublimity of epic narration. But we must be wary of the unnatural sublime that Longinus admonishes us about: "[...] evil are the swellings, both in the body and in diction, which are inflated and unreal, and threaten us with the reverse of our aim; for nothing, say they, is drier than a man who has the dropsy" (Longinus 1974: 77).

If enfiguration injures the ST and robs the TT reader, defiguration does these four fold. It diminishes, depreciates the stylistic quality of the ST and rapes the TT reader of the aesthetic pleasure obtaining in the ST and available for its (ST) audience. The ST has suffered some "diminution" (Steiner 1975: 406), depriving the TT audience of the "imaginative pleasure," the "additional imagery," "emotional intensity" and "concentration" attendant on such figurative use of language (Perrine 1969: 116-117). Such ST impoverishment through defiguration is a likely handiwork of translators who lack the necessary poetic faculty either to recognise the figurativeness (or its importance) or to be able to re-present it in the TT; but it may also be a consequence of the adoption of free translation (rather than a more ST-friendly level of translation) mode as in Clark's Saga where the translator may wish not to give as much attention to the manner or letters of the ST as he does to its matter, spirit or substance. Thus, defiguration is a pitiable disservice to the ST, especially in literary translation. Fortunately, cases of defiguration appear not to be as many as those of enfiguration.

Literal refiguration maintains the total figurative or idiomatic (stylistic) quality of the ST in the TT. The TT audience is given the full opportunity if participating in the Izon figurative or idiomatic culture. Literal refiguation will often result in some strange, cumbersome, even un-English, expressions in the TL, linguistic novelties which the TT reader must strive and struggle to contend with and demystify - such as "if you see a story" (144), "Be strong of body" (204) and "lift up yourself" (303) 
(see 56-58 below). This is the price he has to pay - with pleasure - for his acculturation into the ST (Izon) linguistic literary tradition.

That literal refiguration can be employed successfully even at length is demonstrated by Gabriel Okara, another Izon writer, in his often-cited novel The Voice. In the following sentences the underlined words are literal translations, or "relexifications" of Izon metaphors:

"I have killed many moons, many years in that hut thinking of the happening things in this town. My feet know not the door of a school but Woyengi who all things created gave each of us human beings an inside and a head to think. So many years I have killed in the hut and put many thoughts into my inside which have made me see differently. To speak the straight thing...”

"You asked me why I am giving you my hands in this happening-thing, when you have become the enemy of everything in the town? Well, I am giving you my hands and my inside and my shadow to let them see in their inside that if even the people do not know, we, you and I, know and have prepared our bodies to stand in front of them and tell them so. They now feel that I really am a witch, so I put fear into their insides. That sweetened my inside...(Okara 1964: 54, 56)

The wisdom of adopting such "Africanised English" for creative (literary) purposes has been stressed by several writers and scholars such as Okara himself, (KirkGreene 1971: 127), Chinua Achebe (1975: 61-62), W.R. O’Donnell and Loreto Todd (1991: 139-142), Peter Young (1971: 165-84) and Braj B. Kachru (1983: 41-42). It is crucial particularly for a language like Izon, a large percentage of whose utterances are metaphorical or idiomatic. Translatologists have equally emphasised the relevance of foreign flavour in translations. Thus Wilhelm von Humboldt insists that "a translation should indeed have a foreign flavour to it [...]” (1992: 58). Jose Ortega y Gasset has also remarked as follows:

We need the ancients [foreign texts] to the degree that they are dissimilar to us, and translation should emphasise their exotic, distant character, making it intelligible as such... It is clear that a country's reading public do not appreciate a translation made in the style of their own language. For this they have more than enough native authors. What is appreciated is the inverse: carrying the possibilities of their language to the extreme of the intelligible so that the ways of speaking appropriate to the translated author seen to cross into theirs. (1992: 111-112)

Literal refiguration also curtails to the barest minimum the translator's creative appetite, but it equally tasks his poetic genius to discover and transport the same figurative texture in the ST onto the TT while ensuring that the expression, though unconventional or deviant, remains fairly intelligible to the TT audience who themselves require some poetic faculty to comprehend and appreciate it. Of course, where intelligibility might be largely compromised the translator must resort to annotation to aid the TT reader.

Evidently, literal refiguration marks the apogee of fidelity between the TT and the ST in figurative quality. It conforms to the stand that translation is essentially a re-rendering enterprise rather than a re-creating one.

Alter-figuration results in an effect that dances mid-way between ST enrichment and ST impoverishment. Alter-figuration I exemplifies idiomatic or figurative translation which marks the lowest boundary of fidelity to the ST in being TL-oriented in that it involves "contextual equivalence" where there is the replacement of the ST as 
a figurative texture for the information implied in the ST (Uwajeh 1996a: 3; 1996b: 63). In other words, Clark has replaced Izon figurative (idiomatic) expressions with English figurative expressions, the two indirectly expressing the same information. This indicates some stylistic fidelity, but the ST reader remains alienated from the idiomatic or linguistic tradition of the Izon nation in that he remains with English idioms rather than being made to experience the idioms in the Izon culture.

It is also clear that while two figures of speech may express the same proposition, one of the figures may be more akin to the ST culture than the other. For example in 28 above, the synecdoche tu bono ("sleep-with vagina") is more natural with the mature Izon audience of the ST than the euphemistic "sleep with a woman" or the other understatements. Indeed, it is true with the Izon, as with several other African peoples, that adults should be expected to mention the genitals by their bare "taboo" names, a practice that would sound rather uncouth, raw and offensive to a Western audience. But in saving the TT reader from the embarrassing "vulgarity" or "obscenity," Clark has deprived that same reader of the opportunity to get inducted in, immersed into, Izon speech culture. Hence the probability that the TT reader will shudder at the mention of the sex words is part of the "exotic" character demanded by the Benjamins and the Ortega y Gassets. Secondly, where there is a shift from one trope to another, both expressing the same import, there may be a shift in emphasis or the amount of force. We find this in 31 where Clark has substituted a simile "the girl came walking in, like a goddess of the stream" for a metaphor that should have been "the girl came in, a water-goddess." Since in metaphor the comparison is not expressed but only implied through an equation (in this case, the girl and a goddess), the metaphor is much more forceful than the simile in suggesting the resemblance (or better, the identity) between the girl and a goddess.

Alter-figuration II is an improvement on alter-figuration I and is second only to literal refiguration in that it maintains the figure of speech and alters only the specific terms ("vehicle" or sound). This sub-pattern is legitimised by translatologists. For example, Michael Riffaterre recommends that a literary translation "[...] must semiotize forms and sounds like the original, although in a different system (which is easy: equivalent alliterations, for example, demand only a repetition of sounds, but not necessarily the same sounds as in the source text)" (1992: 204).

Here the loss is little, particularly when, say in alliteration or morpho-phonological reduplication, the effect of the difference in sound is hardly noticed due to the fact that the sounds in both languages often belong to the same general class of consonants or vowels and produce approximately the same foregrounding effect. The alternation in sounds is often a clever move on Clark's part and is sometimes inevitable if the same phonological effect is to be attained.

The difference in effect between Literal refiguration and alter-figuration can be seen more clearly in the following where Clark adopts both patterns:

56a. "Bwo saramoe"

"Let's quicken our steps." (238) - Literal Refiguration

b. "Bwo saramo."

"Double up" (238) - Alter-Figuration II

57a. "Ang serimo an!"

"Buck up!" (303) - Alter-Figuration II

b. Agonodi ango serimo an ba paa.

For Agonodi to bestir herself was now impossible. (306) - Alter-Figuration II 


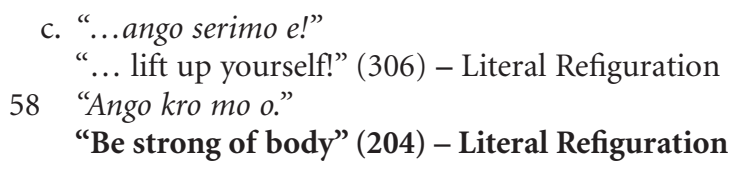

Example 56 (a) can be made even more literal by substituting "legs" (Bwo or buoAgbegha, 1996: 19) for "steps." In 57 and 58 ango is certainly "body" (Agbegha 1996: 8 ) and serimo is "raise" or "lift" (Agbegha 1996: 56). While the cases of literal refiguration sound deviant, the additional labour the TT reader undertakes to appreciate them is rewarded by the new linguistic experience he benefits from.

These issues are crucial because, as K. Lotfipour-Saedi has argued (1992: 195ff), a literary translation should take cognizance of such elements as "degree of indirection" "aesthetic effect," "indeterminacy" and "dehabitualization" - most of which derive from figurative use of language. Lotfipour-Saedi urges us to ensure that "SL textual strategies i.e., special patterns are exactly recreated in the TL e.g., alliteration for alliteration, metaphor for metaphor, rhyming for rhyming" (1992: 202). Furthermore, he insists that

translating SL literary text into a text with special patterns which do not necessarily correlate with those in SL [...] cannot be acceptable because one cannot merely include a few special patterns in his rendering to make it equivalent to SL in terms of literary values: the lexical carrier of the literary patterns in SL and the relationship which is established between these two are also important [...] (Lotfipour-Saedi 1992: 202).

In other words, the translation must ensure balance between the TT and the ST so that the latter has no losses and no gains in the translation enterprise.

\section{Conclusion}

In the above sections we have underlined the fact that figurative language is important in literary translation because literary texts often derive their distinctiveness from the creative (figurative) use of language.We have probed J.P. Clark's The Ozidi Saga and discovered that the translator has adopted about four different patterns in handling figurative expressions in his TT, patterns that we have labelled as enfiguration, defiguration, alter-figuration I and II and literal refiguration.

These patterns have different bearings on the crucial issue of fidelity in literary translation. Specifically, enfiguration and defiguration significantly inflate and deflate (respectively) the stylistic (figurative) quality of the ST through the translation process and bear little fidelity to the ST. alter-figuration, while approximating the literary value of the ST in the TT, fails to enable the TT audience to imbibe the much desired foreign linguistic flavour of the ST culture and may also result in significant modification of the aesthetics or taste relating to the two texts. It is literal refiguration which maintains and transports both the matter and the manner of the ST onto the TT and affords the TT audience the privilege, nay the right, of participating fairly well in the ST Izon culture, although this is not without some cost on his part in having to understand largely unfamiliar idioms.

Two factors may have accounted for Clark's inconsistency in his treatment of figurative language in the translation. The chief factor is the free translation he has adopted which permits him to veer from the letter of the ST in so far as the spirit is captured. Thus, to the general reader, it matters not which of the different patterns is 
adopted or whether Clark translates the same utterance in two or more different patterns. But to the critical ambilingual (bilingual and "biliterate") reader the difference in stylistic effect is apparent and significant. Clark's resort to enfiguration is caused probably by the second factor which is that Clark is a poet-translator who, rather than trim his linguistic prowess, has employed it sometimes unbridled in his translation. But in doing this (satisfying his creative urge) he has presented us with expressions that (unrepresentatively) surpass the aesthetic worth of the ST. Alter-figuration also arises from Clark's assumption of poetic licence, except that it (especially type II) is more discerning and discriminating of the figurative texture of the ST and attempts to give some appreciable equivalence to this texture. In literal refiguration the translator curbs his creative impulse directed at his ego; he employs it (his poetic ingenuity) merely to identify and assimilate the figurative texture or import in the ST expression and reflect it faithfully, literally onto the TT.

The above observations do not amount to an overall conclusive statement that Clark's treatment of figurative language makes his TT on the whole necessarily superior or inferior to the ST. Indeed, there are cases of enrichment, impoverishment and other modification, as well as identity. Any qualitative assessment and judgement of the two texts would consider the intermingling of the different patterns identified and discussed here, along with several other issues that have not been touched in this paper.

\section{NOTES}

1. Compare p.185 where wene takes another metaphor "course through."

2. Clark's translation of ideophones will receive detailed study in another paper.

3. It is doubtful whether the normal mitigation of the unpleasant idea in using the mild "passed out" for "fainted" does serve any purpose in this context other than variety in diction.

4. Care must be exercised in identifying this enfiguration in an Izon text. In

A owei aboko, sisei ye, boe, bo e, bo e! ... O bo kiri di vu

O bo mia kiri di sinya, vu.

Oh male monkey, I pray you, come, oh come, oh come!...

He glanced down only to withdraw.

After peering down here, he withdrew. (28).

there appears to be personification in using the masculine "he" for monkey, which normally takes neuter "it" in English. But this is not personification because in Izon, animals (both male and female) normally take masculine gender grammatically in the choice of the masculine pronoun $\underline{o}$ and in the definite article. Hence "he" is only an admirable literal transfer of the Izon masculine gender for monkey into the English. A note would have clarified this. However, Clark slips a few lines later when he uses "it" for the masculine $\underline{o}$ for the same monkey:

... o famoome bebe pee! O mu tenn agono la tain be ...

... before he could strike, it was off! And back on a tree top ... (28).

5. The word "Trans-Figuration" may also be appropriate but is avoided because of the biblical and other images that may be conjured by "transfiguration."

6. Here Clark has also deleted the word ton ("penis" - Agbegha 1996: 61) in his translation. A faithful translation ought to be “... couldn't see penis to have-sex-with.”

7. The phrase bono ogola should faithfully reader "a sex court."

8. The two meanings of bono appear to be more of homonyms than polysems. The same semantic relationship exists in "sleep" in English, used colloquially for sex.

9. Less euphemistically, bono is also translated in other contexts as "rape" $(279,291)$.

10. Clark's handling of ideophones will be given special treatment elsewhere.

11. The same are is not figurative in

Keme: TEI AREYA AMIE MENE?

Caller: IF YOU SEE GAME, WILL YOU ACT? (154).

where are collocates normally with tei ("game"). 


\section{REFERENCES}

Aвrams, M.H. (1988): A Glossary of Literary Terms, New York, Holt, Rinehart and Winston.

Achebe, C. (1975): Morning Yet on Creation Day: Essays, London, Heinemann.

Agbegha, M.L. (1996): Izon-English Dictionary (Based on the Mein Dialect), Port Harcourt, Riverside Communications.

Bible (KJV and RSV).

Clark, J. P. (1966): Ozidi, London, Oxford University Press.

Clark, J. P. (1977): The Ozidi Saga, Ibadan, Ibadan University Press and Oxford University Press.

Coleridge, S. T. (1973): “The Rime of the Ancient Marriner," in Kermode, F. and J. Hollander (eds), The Oxford. Anthology of English Literature vol. 2., New York, Oxford University Press.

Egudu, R.N. (1979): The Study of Poetry, Ibadan, Ibadan University Press.

Friedrich, H. (1992): "On the Art of Translation," in Schulte, R. and J. Biguenet (eds) Theories of Translation: An Anthology of Essays from Dryden to Derrida, Chicago, University of Chicago Press.

Hawkes, T. (1979): Metaphor, London, Methuen.

Нumboldt, W. von (1992): "From the Introduction to His Translation of Agamemnon" (Trans. SLOAN, S. Theories of Translation).

Ikidden, I. (1982): "Ozidi: The Film, the Saga and the Play," in Asein, S. O. (ed.), Comparative Approaches to Modern African Literiature, Ibadan, University of Ibadan Press.

Kachru, B. B. (1983): "Models for Non-Native Englishes," in Kachru, B.B. (ed.), The Other Tongue: English Across Cultures, Oxford, Pergamon Press.

Kirk-Greene, A. (1971): “The Influence of West African Languages on English,” Spencer, J. (ed.), The English Language in West Africa, London, Longman.

Leech, G. N. (1969): A Linguistic Guide to English Poetry, London, Longman.

Longinus (1974): “On the Sublime," in Dukore, B. F. (ed.), Dramatic Theory and Criticism: Greeks to Grotowski, Fort Worth, Harcourt Brace Jovanovich.

Lotfipour-SAEDI, K. (1992): “Analysing Literary Discourse: Implications for Literary Translation," Meta 37-2, p. 193-203.

O'Donnell, W.R. and T. LoReto (1991): Variety in Contemporary English, London, Harper Collins Academic.

Okara, G. (1964): The Voice, London, Heinemann.

Ortega y Gasset, J. (1992): “The Misery and the Splendour of Translation," (Trans. Gamble Miller, E.), in Schulte and Biguenet (eds), Theories of Translation.

Paz, O. (1992): “Translation: Literature and Letters," (Trans. del Corral, I.), in Schulte and Biguenet (eds), Theories of Translation.

Perrine, L. (1963): Sound and Sense: An Introduction to Poetry, New York, Harcourt Brace and World.

Quirk, R. et al. (1985): A Comprehensive Grammar of the English Language, London, Longman.

Riffaterre, M. (1992): “Transposing Presuppositions on the Semiotics of Literary Translation," in Schulte and Biguenet (eds), Theories of Translation.

Schleiermacher, F. (1992): "From 'On the Different Methods of Translating”" (Trans. Bartscht, W.), in Schulte and Biguenet (eds), Theories of Translation.

Steiner, G. (1975): After Babel: Aspects of Language and Translation, London, Oxford University Press.

Uwajen, M.K.C. (1996a): “Literal Meaning in Performative Translatology," Perspectives: Studies in Translatology 4-2, p. 1-12.

Uwajen, M.K.C. (1996b): “Meaning in Performative Translatology," Tarjuman 5-1, p. 59-80.

Williamson, K. (1965): A Grammar of the Kolokuma Dialect of Ijo, Cambridge, Cambridge University Press. 
326 MetA, LII, 2, 2007

Williamson, K. and A.O. Timitimi (eds.) (1983): Short Izon English Dictionary, Port Harcourt, University of Port Harcourt Press.

Young, P. (1971): “The Language of West African Literature in English,” in SPencer, J. (ed.), The English Language in West Africa, London, Longman. 